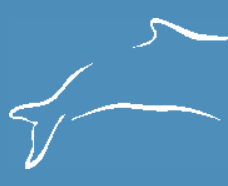

\begin{tabular}{|c|c|}
\hline \multicolumn{2}{|c|}{ Article Info } \\
\hline Manuscript type & Note \\
\hline \multicolumn{2}{|l|}{ Article history } \\
\hline Received & 01 April 2012 \\
\hline Received in revised form & 21 April 2015 \\
\hline Accepted & 04 May 2015 \\
\hline Available online & 26 December 2015 \\
\hline \multicolumn{2}{|c|}{ Keywords: giant otter, population dynamics, distribution } \\
\hline \multicolumn{2}{|c|}{ Responsible Editor: Paul Van Damme } \\
\hline $\begin{array}{l}\text { Citation: Marmontel, M., } \\
\text { O. (2015) Rediscovery of } \\
\text { Sustainable Development } \\
\text { Latin American Journal of } \\
\text { http://dx.doi.org/10.5597 }\end{array}$ & $\begin{array}{l}\text { lvimontes U., J. and Carvalho Jr, } \\
\text { ronura brasiliensis in the Amanã } \\
\text { erve, Amazonas, Brazil. } \\
\text { eatic Mammals 10(2): 147-151. } \\
\text { am00207 }\end{array}$ \\
\hline
\end{tabular}

The giant river otter, Pteronura brasiliensis, is considered vulnerable (Rodrigues et al., 2013) and endangered to extinction $^{1}$ at national and international levels, respectively. The giant otter is a diurnal, semi-aquatic carnivore that forms large groups of up to 14 individuals.

In the past, giant otter distribution covered most of South America, from Venezuela and Colombia east of the Andes to northern Argentina (Harris, 1968; Thornback and Jenkins, 1982; Eisenberg, 1989; Rosas, 2004; Kruuk, 2006; Feuillet and De Thoisy, 2009). As the species inhabits a narrow strip close to riverbanks, it is of easy access to man, which renders it vulnerable to perturbation and hunting (Schenck, 1999). Commercially exploited in the past, giant otter skin was traded for high prices (Brack-Egg, 1978; Smith, 1981), while cubs were captured to serve as pets (Duplaix, 1980). Nowadays giant otters are rare or extinct in a large portion of their original distribution (Eisenberg, 1989; Rosas et al., 1991; Carter and Rosas, 1997), remaining mainly in remote or protected areas (Utreras and Araya, 2002; M. Marmontel, pers. obs).

The Amanã Sustainable Development Reserve is a 2350000 ha protected area located between the Negro and Japurá, and Solimōes river basins and is composed of highlands and white- and blackwater floodplains. One of its main features is a large, $45 \mathrm{~km}$ long and three $\mathrm{km}$ wide black water body, the Amanã Lake. Around the lake there are 12

${ }^{1}$ Groenendijk, J., Duplaix, N., Marmontel, M., Van Damme, P. and Schenck C. (2015) Pteronura brasiliensis. In IUCN Red List of Threatened Species. Version 2015.2. Available online at <www.iucnredlist.org $>$. Consulted on 28 August 2015.

\section{Rediscovery of Pteronura brasiliensis in the Amana Sustainable Development Reserve, Amazonas, Brazil.}

\section{Miriam Marmontel ${ }^{\dagger, *}$, Jorge Calvimontes ${ }^{\ddagger}$ and Oldemar Carvalho Júnior ${ }^{\$}$}

†Instituto de Desenvolvimento Sustentável Mamirauá. Estrada do Bexiga 2584, 69553-225 Tefé, AM, Brazil

${ }^{\ddagger}$ Núcleo de Estudos e Pesquisas Ambientais - NEPAM. Universidade Estadual de Campinas - UNICAMP. Rua dos Flamboyants 155, Cidade Universitária Zeferino Vaz, 13083-867 Campinas, SP, Brazil

sInstituto Ekko Brasil para Conservaçáo da Biodiversidade. Servidão Euclides João Alves, s/n, Lagoa do Peri, Armação do Pântano do Sul, 88066-292 Florianópolis, SC, Brazil

*Corresponding author, email: marmontel@mamiraua.org.br

communities, totaling some 500 local inhabitants, whose livelihoods depend on agriculture, hunting and fishing².

During decades of wildlife trade, between the 1940s and 1970s, Amaná Lake inhabitants hunted giant otters for their pelt, closing the entrance to dens and flushing animals with smoke. The species is believed to have occurred throughout the lake and highland stretches of adjacent creeks, until it was practically eliminated in the area. Since the inception of the wildlife law of 1969, and resulting prohibition of hunting and the disappearance of markets, hunting ceased. However, giant otters had not been observed in the area for several years.

In the early 2000s local inhabitants of the Amanã Lake area reported the presence of giant otters in creeks and even on the lake. This study aimed at confirming the reappearance of giant otters in the area.

Fellow researchers provided the first confirmed information on sighting of dens in the Baré ${ }^{3}$ and Juacaca ${ }^{4}$ creeks, at the Amanã Lake's headwaters in the early 2000s. A quick trip of about four days to Urumutum Creek (Figure 1) in February 2003 confirmed the presence of giant otters through documentation of dens (recently and not recently in use), latrines, tracks and scratch walls. A concerted two-week field effort took place in October 2003 (dry season), following the methods described by Groenendijk et al. (2005). Two survey teams (two researchers, a pilot and a local guide) used sevenmeter aluminum boats equipped with 15 and $30 \mathrm{hp}$ outboard motors (or eventually wooden canoes), and traveled along the

${ }^{2}$ Community Management Program, Mamirauá Institute

${ }^{3}$ M. Cohn-Haft, J.C. Inuma, pers. comm., January 2003.

${ }^{4}$ L. Souza, pers. comm., January 2003. 
greatest possible extension of the main creeks flowing into the Amanã Lake (Figure 1). Sampling extension of creeks ranged from a few up to $80 \mathrm{~km}$. Both headwater (Urumutum, Juacaca, Baré, Ubim, Juá Grande and Juazinho) and lower reaches (Taboca, Ato 80d a local gúma, Cacau, Calafate and Uxi) blackwater creeks were sampled (Table 1, Figure 1). Overnight camping along the margins maximized fuel and time usage. The survey itself consisted in traveling upstream, from each of the creeks' mouth in the Amanã Lake towards its headwaters, at slow speeds (average $6 \mathrm{~km} / \mathrm{h}$ ), observing and searching both shores for signs or remains (dens, campsites, latrines, scats) with the help of binoculars. Notes were taken and the geographical position of each sign was recorded.

\section{Distributional surveys}

Giant otter sign results for each creek are detailed in Table 1. Local inhabitants report that giant otters have reappeared at the Urumutum Creek only since 2001, but that numbers of encounters have been increasing during that period. In the sampled area 50 giant otter signs were found. One adult individual was sighted swimming downstream at 15:20h on 13 October. Close to the mouth of Juacaca Creek, on the Urumutum Creek, old signs of giant otters were found on small land stretches. According to local inhabitants, further upstream there are highland stretches with signs and dens of the species. The Baré Creek showed a positive result for the presence of giant otters, with at least 26 signs, several of which were recent and fresh, with the substrate wet and recently worked by the animals. As reported by local dwellers, giant otters remain in the Juazinho Creek during the flood, and they are repeatedly sighted. During the survey some old giant otter signs were found up to $4 \mathrm{~m}$ high in the highlands. The Calafate Creek, on the other hand, showed no signs of giant otter. The local guide reported that his father sighted giant river otters on a highland stretch of the creek some 30 years earlier. He had then tried to capture it but with no success. No signs of giant otters were found at the Ubim, Juá Grande, Açu, Bacaba, Samaúma, Cacau and Uxi creeks.

The long-term close relationship between researchers and local inhabitants of the protected area, through experiences and information exchange, contributed to the success of the initiative. According to the elderly, giant otters were present and frequently sighted throughout the region of Amaná Lake in the past. The local inhabitants reported hunting techniques and their motivation to capture these animals. At least one case of collection of cubs as pets was reported by an elder; two giant otters lived in close proximity to a community for a few years, returning to sleep from daily trips. The recovery and reappearance of giant otters in the area are always accredited, by locals, to the cessation of harvesting.

Sighting of a giant otter was obtained from only one creek (Urumutum), but three additional creeks (Juacaca, Baré and Juazinho) presented considerable amounts of giant otter sign (dens, latrines, campsites, footprints and scratch walls), confirming the presence of the species in the Amana Sustainable Development Reserve. The Urumutum, Juacaca, Juazinho and Baré creeks are all located in the headwaters of the Amanã Lake, mostly away from human activities and boat traffic. The only creek more closely associated with a local community is the Baré Creek, where otter signs appeared only further upriver from the community area.

This is the first documented case of the recovery of a giant otter population in the Brazilian Amazon after the period of intensive hunting. Recently, giant otters have returned to some areas of their original distribution (Javier Díaz and Sánchez, 2002; Van Damme et al., 2002; Isola, 2004; Recharte and Bodmer, 2009). Some negative perceptions about giant otters by the local human population potentially flame desires for culling individuals. These conflicts are normally related to competition for fish resources and damage of nets, and to a lesser extent to the animals' alleged aggressiveness. Between 2002 and 2004 two giant river otters were killed by gun at the headwaters of the Amanã Lake, and other attempts at killing otters using gun or harpoon were reported. A program started in 2004 to monitor future changes, to visit the aforementioned creeks on a monthly basis, periodically check on the creeks further downstream, and document potential threats and conflicts between human and animal population (Lima et al., 2012). According to a proposed classification of giant otter conservation potential for a given water body (Van Damme and Wallace, 2005), the Aman for culling individuals. These conflicts are normally related to competition for fish resources and damagears have documented more groups of giant otters, occupying greater extensions of the water courses (Lima et al., 2014b) as well as instances of conflicts (Lima and Marmontel, 2011; Lima et al., 2014a). Should the giant otter numbers continue to grow in the area, an environmental education program in the villages surrounding Amaná Lake will be highly desirable to promote awareness among the local inhabitants and reduce the possibility of conflicts.

\section{Acknowledgments}

We warmly thank the local inhabitants of Amanã who showed us the creeks and shared their historical perspective and present views on giant otters. We also thank reviewers who provided comments that improved the original manuscript. This project was conducted with the support of FEPIM (Fundo de Expansão de Pesquisas do Instituto Mamirauá), under number 065 . 
Table 1. Summary of giant otter survey results in Amanã Lake

\begin{tabular}{|c|c|c|c|c|c|c|c|c|c|c|}
\hline Creek & General characteristics & Population and use & $\begin{array}{c}\text { Survey } \\
\text { date }\end{array}$ & $\begin{array}{l}\text { Width } \\
\text { average } \\
(\mathrm{m})\end{array}$ & $\begin{array}{l}\text { Survey } \\
\text { effort } \\
(\mathrm{km})\end{array}$ & $\begin{array}{l}\text { No. } \\
\text { sightings }\end{array}$ & $\begin{array}{l}\text { No. } \\
\text { dens }\end{array}$ & $\begin{array}{c}\text { No. } \\
\text { latrines }\end{array}$ & $\begin{array}{l}\text { No. } \\
\text { camp- } \\
\text { sites }\end{array}$ & $\begin{array}{l}\text { No. } \\
\text { tracks/ } \\
\text { scratch } \\
\text { walls }\end{array}$ \\
\hline Urumutum & $\begin{array}{l}\text { The largest creek. Alternates blackwater } \\
\text { floodplain, low and high levees, and } \\
\text { highland. Low levees in the upper } \\
\text { sections make giant otter presence less } \\
\text { likely. Several other smaller creeks flood } \\
\text { into Urumutum, creating potential } \\
\text { giant otter refuges. Visibility } 1.0 \mathrm{~m} .\end{array}$ & $\begin{array}{l}\text { This creek was a Brazil nut } \\
\text { production site; some areas are } \\
\text { still under seasonal use. There is } \\
\text { now a small community and a } \\
\text { few isolated dwellings }\end{array}$ & $13-17 \mathrm{Oct}$ & $10-50$ & 75.8 & 1 & 10 & 1 & 1 & 38 \\
\hline Juacaca & $\begin{array}{l}\text { Carries white water from the Japurá } \\
\text { River into the Urumutum Creek. } \\
\text { Low margins without banks are } \\
\text { inappropriate for giant otter settlement. } \\
\text { Close to its mouth on the Urumutum } \\
\text { creek, it opens up into many branches } \\
\text { and contains many islands, several of } \\
\text { which remain flooded even during } \\
\text { the dry season. Visibility } 0.6 \mathrm{~m} \text { at the } \\
\text { mouth; depth } 2.3 \mathrm{~m} \text { at the mouth. }\end{array}$ & No settlements & $18 \mathrm{Oct}$ & 10 & 8.9 & - & - & - & - & - \\
\hline Baré & $\begin{array}{l}\text { Starts with a flooded area and evolves } \\
\text { into several highland stretches, } \\
\text { with banks potential for giant otter } \\
\text { occupation. Average width } 30 \mathrm{~m} \text {. }\end{array}$ & $\begin{array}{l}\text { Two large communities, and local } \\
\text { inhabitants tend gardens upriver. }\end{array}$ & $13-15 \mathrm{Oct}$ & 30 & -60 & - & 11 & 3 & 2 & 8 \\
\hline Ubim & $\begin{array}{l}\text { Bordered by low levees, with very } \\
\text { sparse highland stretches. }\end{array}$ & $\begin{array}{l}\text { One extended family community } \\
\text { is located at the entrance of the } \\
\text { creek, local people tend gardens } \\
\text { upstream. }\end{array}$ & $16 \mathrm{Oct}$ & 30 & $<2$ & - & - & - & - & - \\
\hline Juá Grande & $\begin{array}{l}\text { Visibility } 0.5 \mathrm{~m} \text {, depth } 2.9 \mathrm{~m} . \\
\text { Average width } 20 \mathrm{~m} .\end{array}$ & No settlements & $17 \mathrm{Oct}$ & 20 & $<2$ & - & - & - & - & - \\
\hline Juazinho & $\begin{array}{l}\text { Highland creek, the shortest in the } \\
\text { system. Visibility } 0.7 \mathrm{~m} \text {. }\end{array}$ & $\begin{array}{l}\text { Community at the mouth of the } \\
\text { creek, permanently used by local } \\
\text { inhabitants, including tending } \\
\text { gardens }\end{array}$ & $17 \mathrm{Oct}$ & 15 & 4.2 & - & - & - & - & - \\
\hline Açu & $\begin{array}{l}\text { Wide mouth followed by a narrow } \\
\text { water course, with low levees and a few } \\
\text { small highland stretches; low shores } \\
\text { with a few banks. }\end{array}$ & No settlements & $19 \mathrm{Oct}$ & 15 & 8 & - & - & - & - & - \\
\hline Bacaba & $\begin{array}{l}\text { Narrow mouth with thick vegetation; } \\
\text { low levees, with characteristics } \\
\text { inappropriate for giant otter presence. }\end{array}$ & $\begin{array}{l}\text { One small settlement at the } \\
\text { mouth and some gardens }\end{array}$ & $18 \mathrm{Oct}$ & 15 & 3.1 & - & - & - & - & - \\
\hline Samaúma & \multirow{4}{*}{$\begin{array}{l}\text { Floodable habitats with low levees, } \\
\text { with no banks available, therefore } \\
\text { with few possibilities for giant otter } \\
\text { establishment. Average width }-15 \mathrm{~m} \text {. }\end{array}$} & No settlements & $19 \mathrm{Oct}$ & 15 & $<2$ & - & - & - & - & - \\
\hline Cacau & & No settlements & $19 \mathrm{Oct}$ & 15 & $<2$ & - & - & - & - & - \\
\hline Calafate & & Two small settlements at the mouth & $19 \mathrm{Oct}$ & 15 & $<2$ & - & - & - & - & - \\
\hline Uixi & & Small settlement at the mouth & $21 \mathrm{Oct}$ & 15 & $<2$ & - & - & - & - & - \\
\hline
\end{tabular}




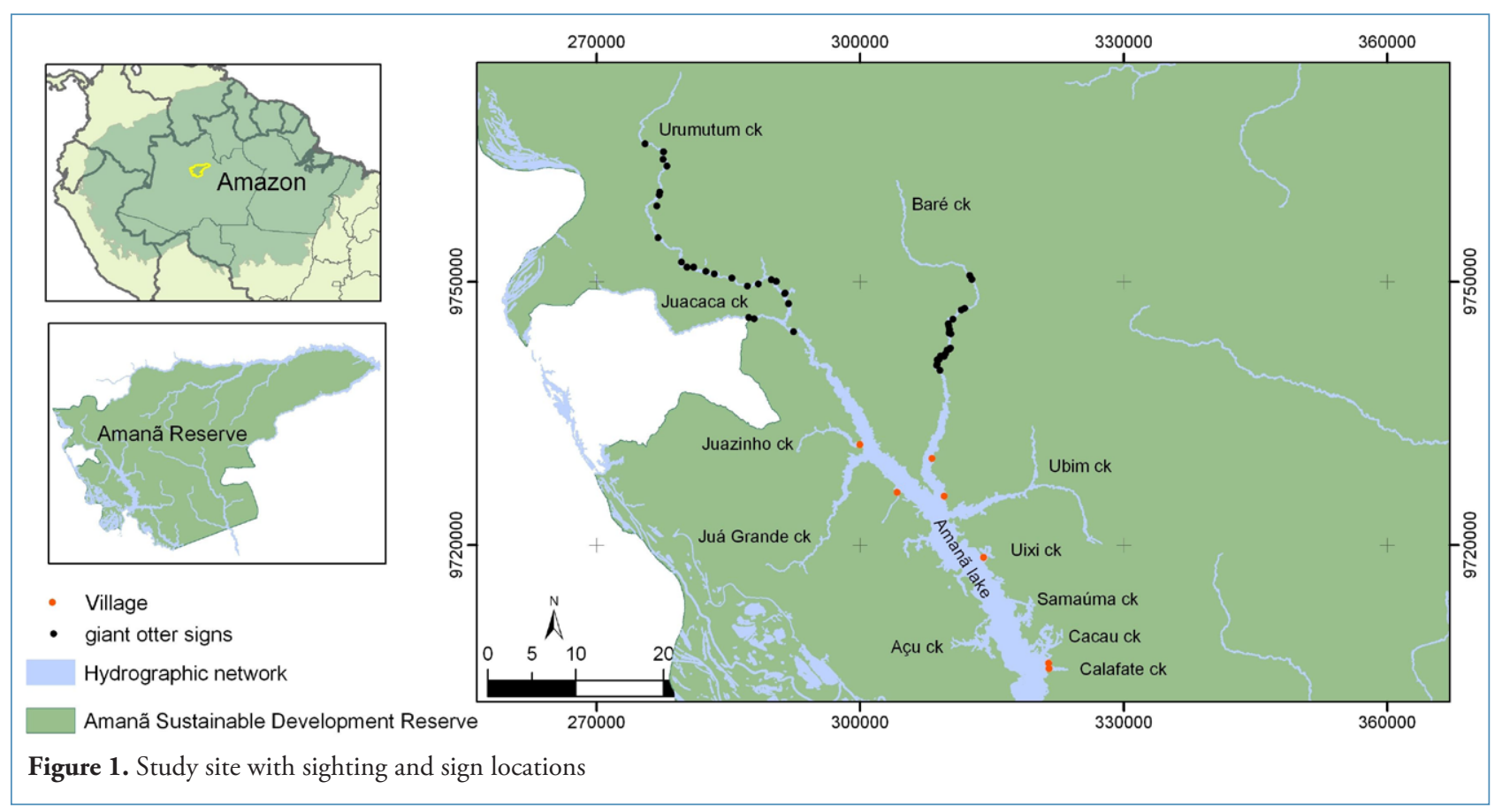

\section{References}

Back-Egg, A. (1978) Situación actual de las nutrias en el Perú. Pages 76-84 in Duplaix, N. (Ed.) Otters; Proceedings of the First Meeting of the Otter Specialist Group. IUCN, Morges.

Carter,S.K., and Rosas, F.C.W. (1997) Biologyand conservation of the giant otter Pteronura brasiliensis. Mammal Review 27(1): 1-26. http://dx.doi.org/10.1111/j.1365-2907.1997. tb00370.x

Duplaix, N. (1980) Observations on the ecology and behaviour of the giant river otter Pteronura brasiliensis in Suriname. Revue Écologique (Terre et Vie) 34: 495-620.

Eisenberg, J.F. (1989) Mammals of the Neotropics, v. 1 The Northern Neotropics: Panama, Colombia, Venezuela, Guyana, Suriname, French Guiana. University of Chicago Press, Chicago. 449 pp.

Feuillet, G., and De Thoisy, B. (2009) La loutre géante. Association Kwata/WWF. 68 pp.

Groenendijk, J., Hajek, F., Duplaix, N., Reuther, C., Van Damme, P., Schenck, C., Staib, E., Wallace, R., Waldemarin, H., Notin, R., Marmontel, M., Rosas, F., De Mattos, G.E., Evangelista, E., Utreras, V., Lasso, G., Jacques, H., Matos, K., Roopsind, I. and Botello, J.C. (2005) Surveying and monitoring distribution and population trends of the giant otter (Pteronura brasiliensis) - guidelines for a standardization of survey methods as recommended by the Giant Otter Section of the IUCN/SSC Otter Specialist Group. Habitat 16(1): 1-100.
Harris, C.J. (1968) Otters: a Study of the Recent Lutrinae. Weidenfeld \& Nicolson, London, UK.

Isola, S. (2004) Distribución y abundancia del lobo de río (Pteronura Brasiliensis) [sic] en la Reserva Nacional Pacaya Samiria, Loreto. Memorias de la Revista Electrónica Manejo de Fauna Silvestre en Amazonía y Latinoamérica: 203-210.

Javier Díaz, H. and Sánchez, I.M. (2002) Historical and actual presence of the giant otter (Pteronura brasiliensis) on the lower Meta River, Department of Casanare - Colombia Orinoquia. IUCN Otter Specialist Group Bulletin 19(2): 97-102.

Kruuk, H. (2006) Otters - ecology, behaviour and conservation. Oxford University Press, Oxford. 265 pp.

Lima, D.S. and Marmontel, M. (2011) Return to the wild and reintegration of a giant river otter (Pteronura brasiliensis) cub to its family group in Amanã Sustainable Development Reserve, Brazilian Amazon. Latin American Journal of Aquatic Mammals 9(2): 164-167. http://dx.doi.org/10.5597/lajam00183

Lima, D.S., Marmontel, M. and Bernard, E. (2012) Site and refuge use by giant river otters (Pteronura brasiliensis) in the Western Brazilian Amazonia. Journal of Natural History 46(11-12): 729-739.

http://dx.doi.org/10.1080/00222933.2011.654280

Lima, D.S., Marmontel, M. and Bernard, E. (2014a) Conflicts between humans and giant otters (Pteronura brasiliensis) in Amanã Reserve, Brazilian Amazonia. Ambiente \& Sociedade XVII(2): 127142. http://dx.doi.org/10.1590/S1414-753X2014000200009 
Lima, D.S., Marmontel, M. and Bernard, E. (2014b) Reoccupation of historical areas by the endangered giant river otter Pteronura brasiliensis (Carnivora: Mustelidae) in Central Amazonia, Brazil. Mammalia 78(2): 177-184. DOI 10.1515/ mammalia-2013-0023

Recharte, M. and Bodmer, R. (2009) Recovery of the endangered giant otter Pteronura brasiliensis on the Yavarí-Mirín and Yavarí Rivers: a success story for CITES. Oryx 44(1): 83-88.

Rodrigues, L.A., Leuchtenberger, C. and Silva, V.C.F. (2013) Avaliação do risco de extinção da ariranha Pteronura brasiliensis (Zimmermann, 1780) no Brasil. Biodiversidade Brasileira 3: 228-239.

Rosas, F.C.W. (2004) Ariranha, Pteronura brasiliensis (Carnivora: Mustelidae). Pages 265-269 in Cintra, R. (Coord.) História Natural, Ecologia e Conservação de algumas espécies de Plantas e Animais da Amazônia. EDUA/INPA/ FAPEAM, Manaus, Brazil.

Rosas, F.C.W., Colares, E.P., Colares, I.G. and Silva, V.M.F. (1991) Mamíferos aquáticos da Amazônia brasileira. Pages 405-411 in Val, A.L., Figliuolo, R. and Feldberg, E. (Eds) Bases Cientificas para Estratégias de Preservação e Desenvolvimento da Amazônia: Fatos e Perspectivas. Vol. 1. INPA, Manaus.

Schenck, C. (1999) Lobo de rio Pteronura brasiliensis - presencia, uso del habitat y protección en el Perú. GTZINRENA, Lima, Peru. 176 pp.
Smith, N.J.H. (1981) Caimans, capybaras, otters, manatees and man in the Amazon. Biological Conservation 19: 177-187. http://dx.doi.org/10.1016/0006-3207(81)90033-1

Thornback, J. and Jenkins, M. (1982) The IUCN Mammal Red Data Book. Part 1: Threatened Mammalian Taxa of the Americas and the Australasian Zoogeographic Region (Excluding Cetacea). IUCN, Gland, Switzerland.

Utreras, V. and Araya, I. (2002) Distribution and conservation status of the Neotropical otter (Lutra longicaudis) and the giant otter (Pteronura brasiliensis) in Ecuador. IUCN Otter Specialist Group Bulletin 19A (Special Issue: Proceedings of the VIIth International Otter Colloquium): 365-369.

Van Damme, P. and Wallace, R.B. (2005) Considerations on measuring giant otter (Pteronura brasiliensis) relative abundance for conservation planning. Revista Boliviana de Ecologia 17: 65-76.

Van Damme, P., Wallace, R., Swaenepoel, K., Painter, L., Ten, S., Taber, A., Gonzalez Jimenes, R., Saravia, I., Fraser, A. and Vargas, J. (2002) Distribution and population status of the giant otter Pteronura brasiliensis in Bolivia. IUCN Otter Specialist Group Bulletin 19(2): 87-96. 